Available online at www.journal.unrika.ac.id

Jurnal KOPASTA

Jurnal KOPASTA, 2 (2), (2015) 106 - 110

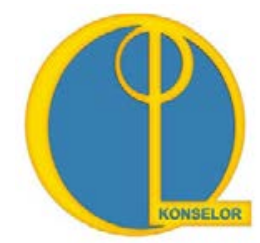

\title{
Keefektifan Layanan Bimbingan Kelompok Ditinjau dari Kepercayaan Diri Siswa Kelas XI IPS di MAN Batam
}

\author{
Ristantia*, Tamama Rofiqah * \\ Division of Counseling and Guidance, University, of Riau Kepulauan, Batam
}

\begin{abstract}
Abstrak
Latar belakang penelitian ini berdasarkan studi pendahuluan pada kelas XI IPS 1 MAN Batam, tingkat kepercayaan diri siswa dalam kategori rendah, adanya gejala seperti; ragu-ragu saat berbicara di depan kelas dalam mengungkapkan pendapat, dan juga saat belajar siswa tidak berani bertanya kepada guru jika tidak tahu atau mengerti apa yang disampaikan oleh Guru pada saat proses belajar mengajar berlangsung. Tujuan dari penelitian ini adalah untuk mengetahui keefektifan layanan Bimbingan Kelompok (Bkp) ditinjau dari kepercayaan diri siswa kelas XI IPS MAN Batam.

Penelitian ini menggunakan metode kuantitatif, desain penelitian yang digunakan adalah kuasieksperimen dengan pretest dan posttest. Sampel penelitian menggunakan teknik purposive sampling. Teknik pengumpulan data mengggunakan angket. Analisa data dilakukan dengan teknik wilcoxon signed ranks test.

Berdasarkan analisis data, diperoleh hasil penelitian dengan nilai signifikan $0.001<0.05$. Berdasarkan temuan penelitian ini disimpulkan bahwa layanan bimbingan kelompok efektif dalam meningkatkan kepercayaan diri siswa.

Kata kunci: Kepercayaan Diri Siswa, Layanan Bimbingan Kelompok.

\section{Pendahuluan}

Kepercayaan diri adalah salah satu aspek kepribadian yang penting pada seseorang. Tanpa adanya kepercayaan diri akan banyak menimbulkan masalah pada diri seseorang. Kepercayaan diri merupakan atribut yang paling berharga pada diri seseorang dalam kehidupan masyarakat. Dikarenakan dengan kepercayaan diri, seseorang mampu mengaktualisasikan segala potensi dirinya. Kepercayaan diri merupakan suatu yang urgen untuk dimiliki setiap individu. Kepercayaan diri diperlukan baik oleh seorang anak maupun orang tua, secara individual maupun kelompok.

Kepercayaan diri yang melekat pada diri individu bukan bawaansejak lahir atau turunan anak melainkan hasil proses belajar bagaimanamerespon berbagai rangsangan dari luar melalui interaksi denganlingkungannya. Kita sering merespon berbagai rangsangan ataufenomena dari luar kemudian kita mempersepsikannya. Bila kitamempersepsikan secara negatif dalam melakukan sesuatu, maka yangditimbulkan adalah perasaanyang tidak menyenangkan kemudian timbul perasaan untuk menghindarinya (Surya :2007).
\end{abstract}

Kenyataan dilapangan, siswa kelas XI IPS 1 MAN Batam saat ini masih ada yang memiliki kepercayaan diri rendah. Hal ini terlihat dari adanya gejala-gejala yakni; ragu-ragu saat berbicara di depan kelas dalam

\author{
*Ristantia \\ *Tamama Rofiqah Telp. 085218281866 E-mail addres: rofiqah87@gmail.com
}


mengungkapkan pendapat, saat belajar siswa tidak berani bertanya kepada guru, siswa takut salah, takut ditertawakan teman sekelas dan juga takut kepada Guru, takut untuk menyampaikan pendapat atau tanggapan saat berdiskusi kelompok. Pada diskusi kelompok inilah mereka cenderung diam dan pasif.Salah satu upaya untuk meningkatkan kepercayaan diri siswa dilakukan melalui layanan bimbingan kelompok.

Menurut Prayitno (2012) bimbingan kelompok mengaktifkan dinamika kelompok untuk membahas berbagai hal yang berguna bagi pengembangan pribadi atau pemecahan masalah individu yang menjadi peserta kegiatan kelompok, dalam bimbingan kelompok dibahas topik-topik umum yang manjadi kepedulian bersama anggota kelompok. Selanjutnya, Mungin (Dalam Narti, 2004) mengemukakan bahwa layanan bimbingan kelompok memungkinkan sejumlah siswa secara bersama-sama melalui dinamika kelompok memperoleh berbagai bahan dari nara sumber tertentu atau dibahas bersama-sama pokok bahasan tertentu yang berguna untuk menunjang pemahaman individu maupun sebagai pelajar untuk mempertimbangkan dalam pengambilan keputusan atau tindakan tertentu.

Adapun rumusan masalah dalam penelitian ini yaitu apakah layanan bimbingan kelompok efektif ditinjau dari kepercayaan diri siswa kelas XI IPS MAN Batam sebelum dan sesudah diberikan layanan ? Tujuan dari penelitian adalah untuk mengetahui apakah layanan bimbingan kelompok efektif ditinjau dari kepercayaan diri siswa kelas XI IPS MAN Batam sebelum dan sesudah diberikan layanan.

\section{Metode Penelitian}

Jenis Penelitian yang digunakan dalam penelitian ini adalah penelitian kuantitatif.Penggunaan metode kuasi eksperimen dilakukan agar dapat mencapai tujuan penelitian yaitu untuk mendapatkan gambaran mengenai kepercayaan diri siswa sebelum dan sesudah mendapatkan perlakuan (treatment) melalui layanan bimbingan kelompok. Adapun desain penelitiannya menurut Sugiono (2013) dapat digambarkan sebagai berikut:

Tabel1. Metode Kuasi Eksperimen

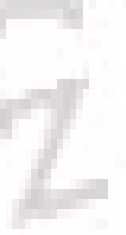

\begin{tabular}{|l|c|c|c|}
\hline KELAS & Pre test & Perlakuan & Post Test \\
\hline Eksperimen & O1 & $\mathrm{X}$ & O2 \\
\hline Kontrol & O3 & - & O4 \\
\hline
\end{tabular}

Keterangan:

$\mathrm{X}=\quad$ Perlakuan dengan menggunakan layanan bimbingan kelompok

$\mathrm{O} 1=\quad$ Kondisi awal kepercayaan diri siswa kelas eksperimen dengan menggunakan instrumen kepercayaan diri siswa

$\mathrm{O} 2=\quad$ Perlakuan dengan menggunakan layanan bimbingan kelompok

O3 $=\quad$ Kondisi awal kepercayaan diri siswa kelas kontrol dengan menggunakan instrumen kepercayaan diri siswa

$\mathrm{O} 4=\quad$ Kondisi akhir kepercayaan diri siswa kelas kontrol dengan menggunakan instrumen kepercayaan diri siswa

Adapun teknik pengumpulan data yang digunakan pada penelitian ini adalah dengan menggunakan angket. Analisis data dilakukan untuk mengetahui efektif tidaknya penerapan metode layanan bimbingan kelompok ditinjau dari kepercayaan diri siswa.Untuk menjawab rumusan masalah yakni melihat perbedaan kepercayaan diri siswa sebelum dan sesudah diberikan perlakuan layanan bimbingan kelompok digunakan analisis dengan teknik wilcoxon signed ranks test. Pengujian dilakukan menggunakan taraf signifikan 0,05, dengan kriteria keputusan dari uji wilcoxon signed ranks testadalah jika nilai signifikansi $>0.05$, maka Ho diterima, dan jika nilai signifikansi $<0.05$, maka Ho ditolak. 


\section{Hasil Penelitian} berikut :

Deskripsi data tentang kepercayaan diri siswa dilihat dari pencapaia skor Pretest dan posttestsebagai

Tabel2.Perbedaan Skor Pretestdan Posttest

\begin{tabular}{|l|l|c|c|c|c|}
\hline No. & Nama (inisial) & $\begin{array}{c}\text { Skor } \\
\text { Pretest }\end{array}$ & Kategori & $\begin{array}{c}\text { Skor } \\
\text { Posttest }\end{array}$ & Kategori \\
\hline 1 & MNW & 102 & Rendah & 136 & Tinggi \\
\hline 2 & FT & 97 & Rendah & 130 & Sedang \\
\hline 3 & FAC & 84 & Rendah & 114 & Sedang \\
\hline 4 & TA & 96 & Rendah & 125 & Sedang \\
\hline 5 & SR & 103 & Rendah & 107 & Sedang \\
\hline 6 & LNS & 102 & Rendah & 128 & Sedang \\
\hline 7 & RS & 99 & Rendah & 127 & Sedang \\
\hline 8 & DK & 93 & Rendah & 117 & Sedang \\
\hline 9 & RA & 97 & Rendah & 115 & Sedang \\
\hline 10 & WHS & 72 & Rendah & 113 & Sedang \\
\hline 11 & MH & 101 & Rendah & 142 & Sedang \\
\hline 12 & ZMM & 86 & Rendah & 128 & Sedang \\
\hline 13 & UM & 100 & Rendah & 118 & Sedang \\
\hline 14 & MI & 96 & Rendah & 138 & Tinggi \\
\hline 15 & MPK & $\mathbf{9 5 , 2 6 6}$ & & $\mathbf{1 2 5 , 2 0 0}$ & \\
\hline & Rata-rata & & & \\
\hline
\end{tabular}

Berdasarkan tabel diatas, pada pretest 15 siswa dalam kategori rendah, tidak ada siswa berada dalam kategori sedangdan kategori tinggi. Pada posttest terdapat peningkatan skor yang signifikan, dimana tidak ada siswa dalam kategori rendah, terdapat 12 siswa berada dalam kategori sedangdan terdapat 3 siswa yang berkategori tinggi.

Analisis data dilakukan dengan menggunakan uji Wilcoxon Signed Ranks Testdengan menggunakan program IBM SPSS Statistics versi 20, dengan taraf signifikansi 0,05. Hasil uji tersebut dapat dilihat pada tabel sebagai berikut :

Tabel 3. Hasil Uji Wilcoxon Signed Ranks Test

\begin{tabular}{|c|l|r|r|r|}
\hline \multicolumn{2}{|c|}{} & \multicolumn{1}{c|}{ N } & \multicolumn{1}{c|}{ Mean Rank } & \multicolumn{1}{c|}{ Sum of Ranks } \\
\hline \multirow{3}{*}{$\begin{array}{c}\text { Posttest } \\
\text { Pretest }\end{array}$} & Negative Ranks & $0^{\mathrm{a}}$ & .00 & .00 \\
\cline { 2 - 5 } & Positive Ranks & $15^{\mathrm{b}}$ & 8.00 & 120.00 \\
\cline { 2 - 5 } & Ties & $0^{\mathrm{c}}$ & & \\
\cline { 2 - 5 } & Total & 15 & & \\
\hline
\end{tabular}

\begin{tabular}{|l|r|}
\hline & Posttest - Pretest \\
\hline $\mathrm{z}$ & $-3.408^{\mathrm{b}}$ \\
\hline Asymp. Sig. (2-tailed) & .001 \\
\hline
\end{tabular}




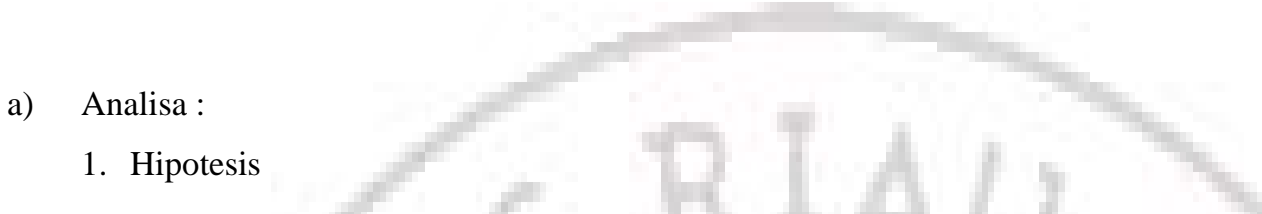

Ho: Tidak terdapat perbedaan keefektifan kepercayaan diri siswa sebelum dan sesudah diberikan layanan bimbingan kelompok.

Ha :Terdapat perbedaan keefektifan kepercayaan diri siswa sebelum dan sesudah diberikan layanan bimbingan kelompok.

2. Kriteria Keputusan

Jika nilai signifikansi $<0,05$, maka Ho ditolak

Jika nilai signifikansi $>0,05$, maka Ho diterima

3. Keputusan

Pada hasil uji Wilcoxon Signed Ranks Test, output signifikansi menunjukkan $0.001<0.05$, dengan demikian Ho ditolak, disimpulkan terdapat perbedaan keefektifan kepercayaan diri siswa kelompok eksperimen sebelum dan sesudah diberikan layanan bimbingan kelompok.

\section{Pembahasan dan Saran}

Hasil penelitian menunjukkan bahwa sebelum diberikan layanan bimbingan kelompok, data awal Pretest pada kelas XI IPS 1 diperoleh hasil kepercayaan diri seluruh 15 siswa berkategori rendah, dan setelah dilakukan layanan bimbingan kelompok data Posttest meningkat yaitu diperoleh 12 siswa berkategori sedang dan 3 siswa berkategori tinggi. Kemudian dilakukan uji hipotesa, maka hasil yang didapatkan yaitu terdapat perbedaan keefektifan kepercayaan diri siswa kelompok eksperimen sebelum dan sesudah diberikan layanan bimbingan kelompok.

Kepercayaan diri itu lahir dari kesadaran bahwa jika memutuskan untukmelakukan sesuatu, sesuatu itu pula yang harus dilakukan. Kepercayaandiri itu akan datang dari kesadaran seorang individu bahwa individutersebut memiliki tekad untuk melakukan apapun, sampai tujuan yang iainginkan tercapai.Menurut Prayitno (2012) Bimbingan kelompok adalah suatu kegiatan yang dilakukan oleh sekelompok orang dengan memanfaatkan dinamika kelompok”. Artinya, semua peserta dalam kegiatan kelompok saling berinteraksi, bebas mengeluarkan pendapat, menanggapi, memberi saran, dan lain sebagainya. Apa yang dibicarakan itu semuanya bermanfaat untuk diri peserta yang bersangkutan sendiri dan untuk peserta lainnya. Melalui wadah bimbingan kelompok ini kepercayaan diri siswa ditumbuhkan. Selain itu kegiatan bimbingan kelompok dapat memberikan manfaat dimana siswa dapat saling menghargai dan menghormati pendapat, kreativitas dalam mengemukakan ide atau pendapat, memperluas wawasan, memberikan pelajaran mengenai pengembangan diri, kesadaran diri serta pandangan baru dalamhubungan dengan lingkungan, dan terbentuk dinamika kelompok bagi para anggota kelompok.

Berdasarkan hasil pembahasan maka disarankan kepada siswa agar dapat mengembangkan serta mengaplikasikan cara-cara berinteraksi yang tepat seperti berani menerima dan menghadapi penolakan orang lain kepada teman ataupun lingkungan sekitar sehinggaperkembangan sosialnya berjalan seimbang dengan kemampuan pola pikir serta selalu mempraktekkanpercaya pada kemampuan diri sendiri agar peningkatan kepercayaan diri dapat berlangsung secara terus menerus. Selain itu saran bagi guru agar senantiasa membangun hubungan kerja sama dengan guru mata pelajaran untuk menciptakan lingkungan yang kondusif dalam meningkatkan kepercayaan diri siswa serta memprogramkan layanan bimbingan kelompok terkait dengan kepercayaan diri siswa yang disesuaikan dengan Need Assesment siswa. 


\section{Daftar Pustaka}

Mungin. (2004), Hartinah, (2009), dan Prayitno (2010) Dalam Narti, Sri (2014) Model Bimbingan Kelompok Berbasis Ajaran Islam Untuk Meningkatkan Konsep Diri Siswa.Yogyakarta: Pustaka Pelajar.

Prayitno. (2012). Jenis Layanan Dan Kegiatan Pendukung Konseling. Padang : FIP-UNP.

Surya, H. (2007). Percaya Diri Itu Penting. Jakarta : Gramedia

Sugiyono. (2013). Metode Penelitian Kuantitatif, Kualitatif dan R\&D. Bandung: Alfabeta. 